\title{
Peningkatan hasil belajar siswa kelas VII dengan strategi Quantum Learning dalam mempelajari IPA materi klasifikasi makhluk hidup melalui penamaan jenis tumbuhan di sekitar madrasah
}

\author{
Nur Sita Hamzati \\ Madrasah Tsanawiyah Darul Ulum Muhammadiyah Galur. Sewugalur, Karangsewu, Kec. Galur, Kulon Progo, Yogyakarta 55661, Indonesia \\ st.hamzati@gmail.com \\ * corresponding author
}

ARTICLE INFO

Keywords

Hasil belajar siswa

Quantum Learning

Klasifikasi makhluk hidup

Jenis tumbuhan

\section{ABSTRACT}

Materi klasifikasi makhluk hidup pada mata pelajaran IPA mengkaji tentang tata nama ilmiah keanekaragaman jenis makhluk hidup. Nama latin menjadi kendala dalam pemahaman siswa karena sulitnya pelafadzan. Sehingga perlu adanya inovasi model pembelajaran agar terjadi proses pembelajaran yang menyenangkan. Penelitian tindakan kelas ini bertujuan untuk meningkatkan hasil belajar siswa dalam mempelajari materi klasifikasi makhluk hidup dengan menggunakan strategi Quantum Learning. Strategi ini menjadikan siswa lebih aktif, karena proses pembelajaran dilakukan dengan santai dan menyenangkan. Pemberian nama atau label pada jenis tumbuhan di lingkungan madrasah merupakan metode penelitian sederhana yang dilakukan oleh siswa dan secara langsung. Sehingga dapat membantu siswa dalam menghafal dan mempelajari keanekaragaman. Hasil belajar siswa mengalami kenaikan persentase capaian KKM dari siklus 1 sebesar $14 \%$ menjadi $62 \%$ pada siklus 2. Meskipun belum mencapai standar ketuntasan individual dan klasikal, namun hasil belajar siswa rata-rata meningkat sebesar $95 \%$.

This is an open access article under the CC-BY-SA license.

\section{PENDAHULUAN}

Belajar merupakan sebuah proses adaptasi (penyesuaian tingkah laku) yang berlangsung secara progresif (Syah, 2013) dan terjadi dari hasil latihan atau pengalaman (Purwanto et al., 2009). Selanjutnya kemampuan yang diperoleh anak setelah melalui kegiatan belajar hingga mencapai tujuan pembelajaran disebut sebagai hasil belajar (Abdurrahman, 2003). Namun, ada faktor yang mempengaruhi mempengaruhi proses pembelajaran yaitu metode atau cara belajar siswa (Syah, 2013). Pembelajaran yang dilakukan secara monoton kurang bervariasi lebih cepat membosankan sehingga membuat siswa enggan atau malas untuk mengikuti pembelajaran (Widayati, 2016).

Setiap sekolah yang memiliki kualitas baik, maka akan melakukan berbagai macam strategi untuk meningkatkan mutunya. Salah satu langkah untuk meningkatkan kualitas siswa yaitu memaksimalkan peran guru untuk menyusun strategi pembelajaran. Oleh karena itu, strategi pembelajaran perlu dilakukan untuk mendukung kualitas siswa yang dihasilkan. Khususnya pada penerapan Kurikulum 2013, setiap guru diharapkan mampu membimbing siswa untuk melakukan pembelajaran yang aktif, inovatif, kreatif dan menyenangkan. 
Secara umum, siswa aktif akan selalu berusaha untuk menanyakan banyak pengalaman yang dijumpainya. Salah satu metode pembelajaran yang dapat menarik minat siswa untuk senang belajar yaitu Quantum Learning. Manfaat penggunaan metode Quantum Learning adalah meningkatkan peran pelajar menjadi bertanggung jawab sehingga dapat meningkatkan kualitas diri serta lingkungannya. Dasar pemikiran dari metode ini adalah untuk memunculkan karakter siswa untuk selalu belajar aktif (Purba, 2009) (DePorter, 2002). sehingga dapat mengembangkan potensi diri (Purba, 2009) (Herbowo, 1999).

Materi klasifikasi makhluk hidup pada mata pelajaran IPA merupakan materi pengenalan dasar yang diberikan untuk siswa kelas VII untuk mengenal kekayaan alam. Sebagai siswa baru, kelas VIIA khususnya mulai kesulitan dalam mempelajari istilah asing yang begitu banyak. Banyaknya komponen yang harus dipelajari pada materi tersebut menjadikan siswa mengalami kendala dalam menulis dan menghafalkan penamaan ilmiah. Di sisi lain, dalam kehidupan sehari-hari para siswa sering menjumpai beberapa makhluk hidup yang dipelajari di lingkungan sekitar mereka. Oleh karena itu, peneliti melalukan penelitian tindakan kelas dengan menggunakan strategi Quantum Learning untuk membantu menangani permasalahan yang terjadi pada siswa kelas VII dalam menyelesaikan materi Klasifikasi Makhluk Hidup.

\section{METODE}

Penelitian tindakan kelas ini dirancang berdasarkan model penelitian tindakan dari Kemmis dan Taggart dalam Sugiarti, 1997, yaitu berbentuk spiral, mulai dari siklus yang satu ke siklus yang berikutnya. Setiap siklus meliputi planning (rencana), action (tindakan), observation (pengamatan), dan reflection (refleksi). Pada pelaksanaan penelitian tindakan kelas ini, akan mengikuti 2 siklus, seperti alur yang terdapat pada skema berikut.

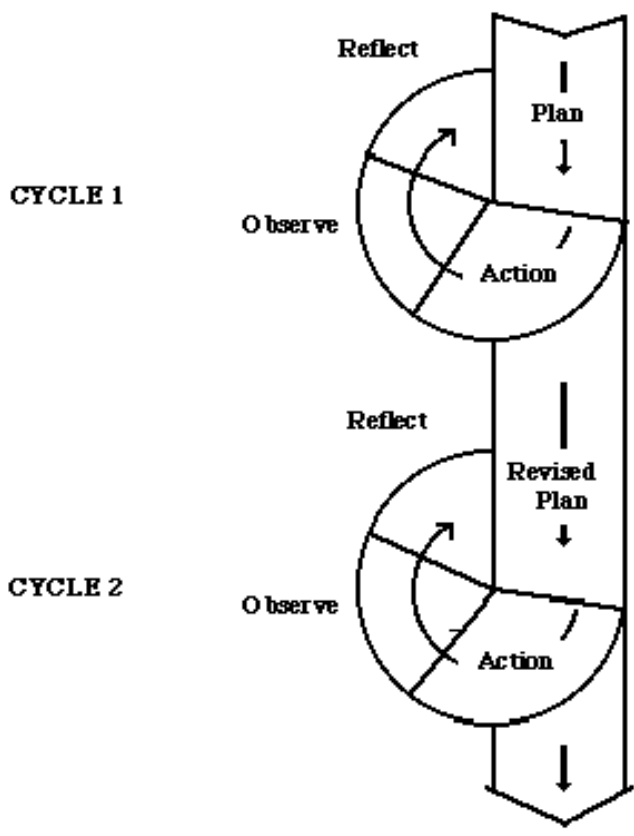

Gambar 1. Siklus penelitian tindakan kelas (MacIsaac, 1995; O’Brien, 1998)

Prosedur analisis data dalam penelitian ini adalah menghitung distribusi frekuensi nilai hasil evaluasi siswa dengan menggunakan rumus sebagai berikut:

$\mathrm{P}=\frac{f}{N} \times 100 \%$

Keterangan

$\mathrm{P}=$ Persentase anak yang tuntas dalam belajar

$\mathrm{f}=$ Jumlah anak yang tuntas dalam belajar

$\mathrm{N}$ = Jumlah anak keseluruhan 
Membandingkan ketuntasan belajar anak dari pra tindakan, siklus 1 dan siklus 2. Adapun kriteria keberhasilan yang dipakai dalam pengujian hipotesis adalah hipotesis diterima atau tindakan dinyatakan berhasil jika siswa mencapai ketuntasan individual $\geq 75$ dan ketuntasan klasikal $\geq 80 \%$ dari seluruh siswa yang mencapai ketuntasan individual. Data ini diambil dari tes evaluasi yang diberikan di setiap akhir siklus (Widayati, 2016).

\section{HASIL DAN PEMBAHASAN}

\section{Kondisi Awal Siswa}

Siswa kelas VIIA MTs Darul 'Ulum Muhammadiyah Galur merupakan siswa unggulan madrasah. Jumlah siswa dalam satu kelas yaitu 21 anak yang terdiri atas 11 siswa dan 10 siswi. Secara akademik, nilai rata-rata klasikal dari kelas VIIA adalah 50. Perolehan ini berdasarkan hasil evaluasi yang diperoleh dari materi sebelumnya yaitu materi klasifikasi materi. Materi klasifikasi makhluk hidup adalah materi yang menyebutkan banyak istilah latin yang tidak pernah disinggung sama sekali di tingkat Sekolah Dasar. Sehingga, istilah ini cukup menyulitkan siswa dalam mempelajari, melafadzkan dan menghafalkan. Selain itu, banyaknya cakupan materi yang harus dipelajari juga menyebabkan siswa semakin malas untuk belajar dan menghafal.

Pada dasarnya materi klasifikasi makhluk hidup adalah materi untuk mengenalkan siswa mengenai kekayaan alam sekitar kita. Jika penyampaian materi dilakukan dengan ceramah maka akan terkesan monoton dan membosankan. Oleh karena itu, pembelajaran di dalam kelas sangat kurang tepat. Sehingga dalam penelitian ini, setiap siswa dituntut untuk berperan aktif dalam melakukan aktifitas pembelajaran, khususnya mengenal dan mempelajari makhluk hidup yang ada di lingkungan sekitarnya.

Awalnya, siswa diberi pemahaman mengenai pengenalan materi klasifikasi makhluk hidup di ruang kelas. Namun, para siswa terlihat bingung dan tidak mempunyai gambaran mengenai materi. Sehingga, seluruh siswa diajak untuk keluar kelas menuju halaman dan mengenal kekayaan alam yang ada di sekitarnya. Secara sekilas, jika siswa diberi pertanyaan mengenai macam-macam jenis tumbuhan di sekitar madrasah, maka hampir seluruh siswa menjawab tidak mengetahui jenisnya. Padahal, setiap siswa selalu melihat bagian dari tumbuhan tersebut. Oleh karena itu, kebiasaan siswa ini perlu mendapatkan penanganan lebih lanjut dalam mengenal dan mempelajari jenis-jenis makhluk hidup yang terdapat di sekitar kita. Pembelajaran di luar kelas menjadi salah satu model pembelajaran yang menyenangkan melalui strategi Quantum Learning.

\section{Deskripsi Data}

Pada bagian ini disajikan data hasil penelitian tindakan kelas. Penelitian ini tentang pembelajaran IPA materi klasifikasi makhluk hidup melalui penamaan jenis tumbuhan di sekitar madrasah. Strategi pembelajaran yang digunakan dalam penelitian ini adalah Quantum Learning. Pelaksanaan penelitian ini menggunakan 2 siklus menurut Kemmis dan Taggart.

\section{Siklus 1}

Pada siklus 1, penelitian tindakan kelas secara umum terdiri atas 4 tahapan kegiatan, yaitu perencanaan, pelaksanaan, observasi dan refleksi.

\section{Tahap Perencanaan}

Pada tahap perencanaan, penulis melakukan kegiatan yang meliputi penyiapan Rencana Pelaksanaan Pembelajaran (RPP), bahan dan media pembelajaran, lembar kerja praktikum, instrumen pengamatan, dan instrumen evaluasi terkait dengan persiapan pelaksanaan pembelajaran IPA materi klasifikasi makhluk hidup.

Tahap Pelaksanaan

Pelaksanaan pembelajaran materi klasifikasi makhluk hidup pada tahap ini menggunakan strategi Quantum Learning. Tindakan perbaikan melalui pembelajaran siklus 1 terdiri atas terdiri atas 5 Jam Pembelajaran untuk menyelesaikan Kompetensi Dasar seperti yang tercantum pada silabus. Setiap kali pertemuan pembelajaran terdiri atas tiga tahapan, yaitu kegiatan pendahuluan, inti dan penutup. 


\section{Kegiatan Pendahuluan}

Pada kegiatan pendahuluan, penulis memulai dengan: memberi salam, berdoa dan mengabsen siswa, kegiatan apersepsi dan motivasi, serta menyampaikan tujuan pembelajaran, kegiatan Inti Pembelajaran, kegiatan inti pembelajaran dimulai dengan penyampaian materi pengantar bab klasifikasi makhluk hidup. Berikut ini merupakan runtutan kegiatan pembelajaran yang dilakukan: (1) Menyampaikan materi pengantar klasifikasi makhluk hidup dengan media pembelajaran yang telah disiapkan; (2) Membentuk kelompok masing-masing terdiri atas 5-6 siswa secara acak; (3) Menyampaikan cara diskusi kelompok dan penelitian; (4) Membagikan lembar kerja praktikum; (5) Siswa melakukan pembelajaran di luar kelas dengan melakukan penelitian terhadap jenis tumbuhan di lingkungan madrasah; (6) Hasil dari penelitian didiskusikan dan dipresentasikan di kelas; (7) Selanjutnya siswa mencari klasifikasi ilmiah dari jenis tumbuhan melalui media internet

\section{Kegiatan Penutup}

Setelah melaksanakan kegiatan inti, penulis melaksanakan kegiatan penutup yang meliputi: (1) Siswa dan guru membuat rangkuman dan kesimpulan bersama; (2) Siswa dan guru melakukan penelitian atau refleksi terhadap kegiatan yang sudah dilakukan; (3) Guru memberikan umpan balik terhadap proses dan hasil pembelajaran; (4) Guru menyampaikan rencana pembelajaran selanjutnya; (5) Guru memberikan tugas rumah (tidak terstrukur); (6) Guru mengakhiri pembelajaran dengan doa dan salam

\section{Tahap Observasi}

Pada tahap observasi, penulis melakukan pengamatan terhadap jalannya kegiatan pembelajaran, khususnya terkait dengan keaktifan siswa serta rasa ingin tahunya terhadap materi pembelajaran Klasifikasi Makhluk Hidup. Tahap observasi dilakukan secara berkala, mulai dari penulis menyampaikan materi hingga materi selesai disampaikan dalam satu kali pertemuan. Setiap siswa diberi kesempatan untuk aktif bertanya dan setiap kelompok diberi waktu untuk berdiskusi. Pada saat berdiskusi, keterlibatan setiap anggota untuk menyampaikan pendapat dan pembagian tugas masih kurang. Namun, seluruh siswa saling menghargai terhadap pendapat orang lain dan saling bekerja sama untuk membantu temannya untuk belajar. Selanjutnya, siswa diberi tugas secara tidak terstruktur untuk menjawab pertanyaan-pertanyaan singkat (mencongak) mengenai materi yang disampaikan. Berdasarkan hasil pengamatan penulis, sudah banyak siswa yang antusias terhadap penyampaian materi, tetapi ada juga beberapa siswa yang pasif bahkan kurang memperhatikan.

Pelaksanaan materi pengantar ini cukup membuat siswa senang, karena siswa dikelompokkan secara acak. Selain itu, model tempat duduk juga dibuat melingkar, sehingga proses diskusi berjalan cukup baik dan kondusif. Tidak ditemukan siswa yang bermain sendiri, karena seluruh siswa fokus terhadap materi yang disampaikan melalui LCD.

Tabel 1. Hasil belajar siswa pada siklus 1

\begin{tabular}{ccc}
\hline \multirow{2}{*}{ Hasil Belajar Siswa } & \multicolumn{2}{c}{ Kategori } \\
\cline { 2 - 3 } & Belum Memenuhi KKM & Sudah Memenuhi KKM \\
\hline Jumlah Siswa & 18 siswa & 3 siswa \\
Pesentase & $86 \%$ & $14 \%$ \\
\hline
\end{tabular}

Pada akhir tahap siklus 1, kemampuan belajar siswa diuji dengan menggunakan tes evaluasi belajar. Tes evaluasi belajar tentang materi pengantar klasifikasi makhluk hidup diikuti oleh siswa dengan antusias, namun tidak sedikit pula yang merasa acuh dalam mengerjakan tes. Berdasarkan hasil penelitian, rata-rata hasil belajar siswa pada siklus 1 diperoleh $45,81 \%$. Persentase perolehan nilai secara klasikal ini termasuk kecil dan kurang maksimal dalam melakukan pembelajaran.

\section{Tahap Refleksi}

Pada tahap refleksi, penulis mengevaluasi hasil belajar siswa pada siklus 1 dengan menyatakan bahwa rata-rata seluruh siswa masing kurang memenuhi syarat ketuntasan. Oleh karena itu, perlu adanya tindak lanjut atau pelaksanaan siklus 2 untuk meningkatkan hasil belajar melalui strategi Quantum Learning dalam mempelajari materi Klasifikasi Makhluk Hidup. Hasil belajar dengan menggunakan kegiatan ceramah dan tahap penelitian keanekaragaman jenis makhluk hidup masih 
belum mencapai kriteria keberhasilan. Selanjutnya, untuk meningkatkan hasil belajar siswa, metode Quantum Learning ditingkatkan dengan menggunakan tugas terstruktur. Siswa melakukan pencarian di internet mengenai jenis tumbuhan yang telah diamati. Kemudian siswa membuat klasifikasi ilmiah berupa etiket pada jenis-jenis tumbuhan yang ada di lingkungan madrasah.

\section{Siklus 2}

Pada siklus 2, pelaksanaan pembelajaran melanjutkan siklus 1, dimana kegiatan belajar mengajar adalah mengulas materi tentang keanekaragaman makhluk hidup serta melanjutkan hasil penelitian. Siklus 2 meliputi perencanaan, tindakan, observasi dan releksi.

\section{Tahap Perencanaan}

Perencanaan pada siklus 2 sama dengan siklus 1, akan tetapi lebih mengutamakan proses penamaan jenis tumbuhan di lingkungan madrasah sehingga dapat terjadi peningkatan hasil belajar melalui keaktifan siswa.

Tahap Pelaksanaan

Pada tahap perencanaan setiap kali pertemuan pembelajaran terdiri atas tiga kegiatan, yaitu kegiatan pendahuluan, inti dan penutup. Kegiatan Pendahuluan. Pada kegiatan pendahuluan, penulis memulai dengan: memberi salam, berdoa dan mengabsen siswa, kegiatan apersepsi dan motivasi, dan serta menyampaikan tujuan pembelajaran.

Kegiatan Inti Pembelajaran. Kegiatan inti pembelajaran dimulai dengan penyampaian materi pengantar bab Klasifikasi Makhluk Hidup serta memberikan penjelasan tentang langkah-langkah pembelajaran dengan strategi Quantum Learning. Berikut ini merupakan runtutan kegiatan pembelajaran yang dilakukan; (1) Membentuk kelompok masing-masing terdiri atas 5-6 siswa secara acak; (2) Menyampaikan cara diskusi kelompok dan penelitian; (3) Membagikan lembar kerja praktikum; (4) Siswa melakukan pembelajaran di luar kelas dengan melakukan penelitian terhadap jenis tumbuhan di lingkungan madrasah; (5) Hasil dari penelitian didiskusikan dan dipresentasikan di kelas; (6) Selanjutnya siswa mencari klasifikasi ilmiah dari jenis tumbuhan melalui media internet; (7) Menyampaikan pengarahan kepada siswa terkait dengan cara membuat taksonomi tumbuhan serta cara penulisan ilmiah; (8) Siswa diminta untuk menempelkan label tumbuhan tersebut dengan ditancapkan di tanah atau digantungkan agar tidak merusak tanaman; (9) Setiap siswa diwajibkan untuk menghafalkan klasifikasi dari jenis-jenis tumbuhan yang telah diberi nama serta menuliskannya kembali.

\section{Kegiatan Penutup}

Setelah melaksanakan kegiatan inti, penulis melaksanakan kegiatan penutup yang meliputi: (1) Siswa dan guru membuat rangkuman dan kesimpulan bersama; (2) Siswa dan guru melakukan refleksi terhadap kegiatan yang sudah dilakukan; (3) Guru memberikan umpan balik terhadap proses dan hasil pembelajaran; (4) Guru menyampaikan rencana pembelajaran selanjutnya; (5) Guru memberikan tugas rumah (tidak terstrukur); (6) Guru mengakhiri pembelajaran dengan doa dan salam.

Pengamatan pelaksanaan pembelajaran menggunakan instrumen penilaian yang telah disiapkan dengan dibantu oleh kolaboran. Tugas dari kolaboran adalah mengamati setiap aktivitas siswa dan situasi kelas secara keseluruhan, yaitu keaktifan dan peran siswa dan data hasil belajar siswa.

\section{Tahap Observasi}

Pada siklus 2 terjadi peningkatan aktivitas belajar dan keaktifan siswa untuk berperan serta dalam melakukan penamaan jenis tumbuhan. Aktivitas siswa ini terlihat setiap pagi hari, dimana seluruh siswa kelas VIIA selalu mengamati jenis-jenis tumbuhan yang berada di lingkungan madrasah. Bahkan, dalam satu kelompok saling membagi tugas dalam menyelesaikannya.

Partisipasi dan kepedulian untuk menyelesaikan tugas dalam satu kelompok mulai meningkat. Peningkatan ini dilihat dari proses pembagian tugas siswa ketika proses siklus 2 berlangsung. Pada siklus ini menitikberatkan pemahaman siswa dalam mempelajari materi dengan metode yang menyenangkan. Sehingga setiap siswa diberi kesempatan untuk menempelkan klasifikasi tumbuhan. Terlihat antusias siswa ketika berebut untuk menempelkan label pada jenis tumbuhan 
yang telah diamati pada siklus 1. Kepedulian siswa untuk saling membantu satu sama lain juga terlihat ketika menempelkan label, tidak hanya satu kelompok bahkan antar kelompok.

Tabel 2. Hasil belajar siswa pada siklus 2

\begin{tabular}{ccc}
\hline \multirow{2}{*}{ Hasil Belajar Siswa } & \multicolumn{2}{c}{ Kategori } \\
\cline { 2 - 3 } & Belum Memenuhi KKM & Sudah Memenuhi KKM \\
\hline Jumlah Siswa & 8 siswa & 13 siswa \\
Pesentase & $38 \%$ & $62 \%$ \\
\hline
\end{tabular}

Keaktifan siswa dalam penelitian ini sangat baik, karena hampir secara keseluruhan siswa terlibat dalam pelaksanaan. Namun, dengan strategi pembelajaran Quantum Learning ini masih menjadikan siswa kurang teliti dalam mengerjakan tes. Ketepatan hasil dari tugas masih banyak yang diabaikan meskipun penyelesaian tugas dapat tepat waktu. Secara kuantitatif, perolehan hasil belajar pada siklus 2 yaitu $62 \%$.

\section{Tahap Refleksi}

Berdasarkan hasil observasi dari siklus 2, maka hasil belajar siswa kelas VIIA MTs Darul Ulum Muhammadiyah Galur sudah mengalami peningkatan. Meskipun masih ada yang belum tuntas, namun secara kualitatif peningkatan hasil belajar dengan menggunakan strategi Quantum Learning cukup efektif. Siswa sangat terbantu dalam mempelajari materi yang sulit menjadi mudah dan menyenangkan.

Pada tahap ini, penulis mengevaluasi bahwa bagi siswa yang belum memenuhi KKM maka, setiap siswa yang tidak tuntas membentuk kelompok baru, selanjutnya menyelesaikan tugas pengganti. Oleh karena itu, adanya tugas pengganti ini diharapkan mampu memenuhi standar KKM. Sehingga, penelitian tindakan kelas ini berhenti pada siklus 2.

Pelaksanaan belajar dengan menggunakan strategi Quantum Learning dalam mempelajar Klasifikasi Makhluk Hidup membutuhkan persiapan dan perhatian yang banyak. Hasil belajar dengan menggunakan metode ceramah tidak cukup memberi pemahaman. Sehingga melakukan praktek menjadi langkah yang tepat bagi siswa agar mudah dalam mempelajari.

Penggunaan strategi pembelajaran Quantum Learning menggunakan prinsip belajar menyenangkan. Model belajar yang menyenangkan merupakan model pembelajaran yang terjadi dalam dua arah. Guru memberikan demonstrasi aplikasi materi pembelajaran kepada siswa, serta siswa menyampaikan hasil penyelidikan dan gagasannya kepada guru. Sehingga penyampaian materi menjadi komunikatif dan menarik.

Pada awal pembelajaran, siswa diberi bekal materi pengantar Klasifikasi Makhluk Hidup. Penyampaian materi ini disampaikan dengan media visualisasi yaitu laptop dan LCD. Seluruh siswa memperhatikan dengan serius, bahkan beberapa siswa mulai tertarik untuk melakukan diskusi terbuka. Sehingga, untuk mengetahui keaktifan siswa, maka dalam satu kelas dibagi menjadi empat kelompok secara acak, dimana masing-masing kelompok terdiri atas 5-6 siswa.

Pada proses pelaksanaan, setiap kelompok diberi kesempatan untuk melakukan diskusi, kemudian salah satu siswa dari perwakilan kelompok diberi waktu untuk menyampaikan hasil diskusi. Berdasarkan hasil pengamatan, diperoleh bahwa komunikasi dan keaktifan siswa mulai terbentuk melalui diskusi ini. Rasa senang siswa yang awalnya pasif, mulai mencoba berkomunikasi menyampaikan pendapat kepada temannya. Sehingga setelah penyampaian materi pengantar, seluruh siswa yang terbagi ke dalam 4 kelompok tersebut diajak melakukan pengamatan jenis-jenis tumbuhan di sekitar madrasah. 

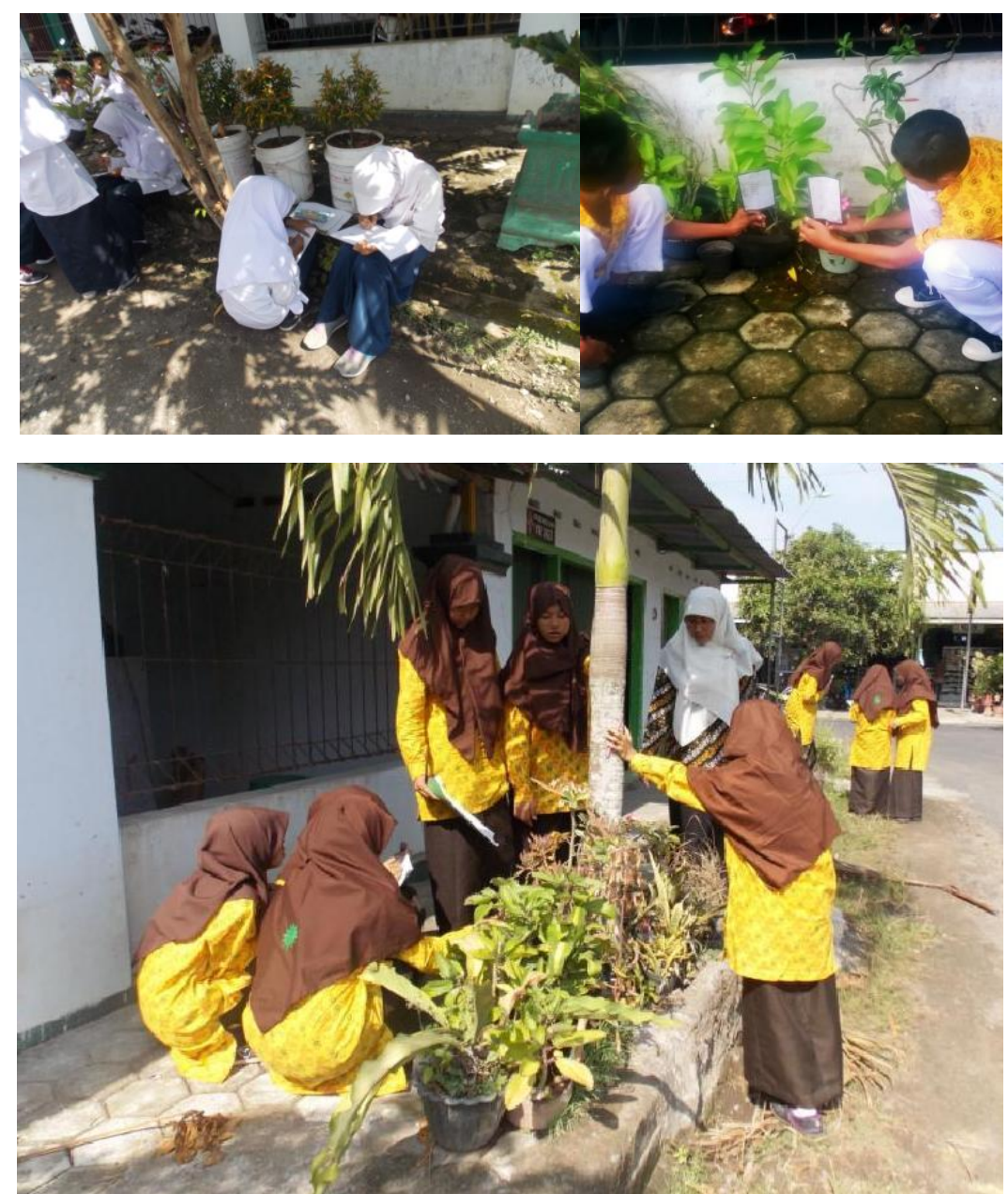

Gambar 1. Pengamatan jenis-jenis tumbuhan di sekitar madrasah

Selanjutnya para siswa melakukan penelitian di lingkungan madrasah, dimana obyek yang diamati adalah jenis-jenis tanaman yang berada di lingkungan madrasah. Para siswa mulai mengamati, mencatat, membuat sketsa dari setiap jenis tumbuhan. Setiap kelompok harus mengamati jenis tumbuhan yang berbeda. Proses pengamatan jenis-jenis tumbuhan ini diikuti oleh seluruh siswa dengan antusias yang tinggi. Masing-masing siswa selalu ingin terlibat dalam melakukan pengamatan.

Setelah siswa melakukan penelitian, hasil dari pengamatan dikumpulkan dan dibimbing guru untuk pembetulan. Selanjutnya siswa mencari informasi klasifikasi ilmiah dari jenis tumbuhan yang telah diamati di internet. Melalui media internet, diharapkan para siswa secara tidak langsung belajar Teknologi Informasi (TI) serta dapat mengoreksi kesalahan.

Akan tetapi, hasil pengamatan menunjukkan bahwa masih banyak siswa yang kurang teliti terhadap pekerjaannya. Pengarahan dari guru masih sangat diperlukan untuk membimbing proses pembetulan. Sehingga, dalam hal ini siswa masih kesulitan untuk membuat kesimpulan. Oleh karena itu, pembetulan dan pengarahan guru masih diperlukan untuk membimbing siswa kelas VIIA dalam penguasaan TI maupun penarikan kesimpulan.

Setelah proses pembetulan, maka pada pertemuan berikutnya, siswa wajib membuat etiket atau penamaan yang ditempel pada jenis tumbuhan yang diamati. Sehingga, setelah penempelan etiket, lingkungan sekitar madrasah dapat digunakan untuk media pembelajaran, baik oleh siswa dalam tingkatan kelas yang sama maupun oleh tingkat yang berbeda.

Materi Klasifikasi Makhluk Hidup merupakan materi yang cakupannya sangat luas. Banyaknya penulisan istilah dan nama ilmiah menjadikan siswa sulit memahami materi ini. Selain itu, metode mengajar yang hanya terjadi satu arah dari guru ke siswa cenderung kurang menarik dan 
membosankan. Namun, dengan strategi Quantum Learning ini, siswa diberi kesempatan untuk berdiskusi serta melakukan pembelajaran secara aktif.

Berdasarkan hasil penelitian diperoleh bahwa hasil belajar pada siklus I dan II terjadi peningkatan. Peningkatan hasil belajar ini dilihat dari perbedaan proses pembelajaran dari siklus 1 dan siklus 2. Pembelajaran pada siklus 1 hanya dilakukan sebatas siswa mengamati jenis tumbuhan tanpa menyebutkan klasifikasi ilmiah dari jenis-jenis tumbuhan. Sehingga, materi klasifikasi ilmiah masih belum dapat dipahami sepenuhnya. Sedangkan pada siklus 2, siswa diharuskan membuat klasifikasi atau penamaan jenis tumbuhan. Model pembelajaran yang menyenangkan serta diulang-ulang ini menjadikan hasil belajar siswa menjadi meningkat.

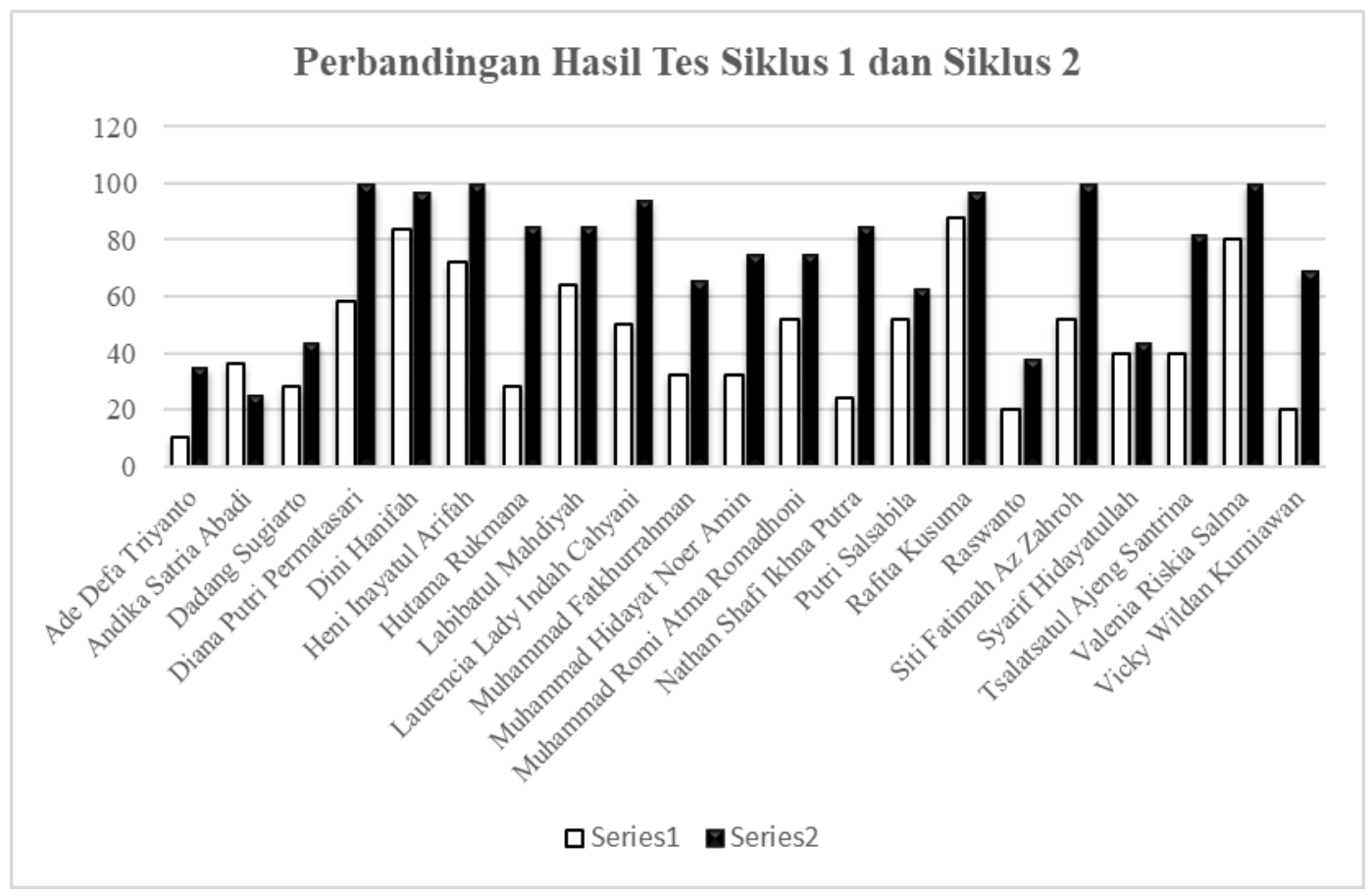

Gambar 2. Grafik Perbandingan Hasil Belajar Siswa pada Siklus 1 dan Siklus 2

Berdasarkan hasil tes evaluasi dari siklus 1 dan siklus 2, maka sebanyak 20 siswa mengalami peningkatan hasil belajar, namun tidak semuanya memenuhi KKM. Satu siswa mengalami penurunan nilai, hal ini dikarenakan kondisi siswa ketika mengikuti pembelajaran masih kurang serius. Pada materi pengantar, siswa tersebut mengikuti proses pembelajaran dengan baik, namun ketika proses penelitian siswa kurang dapat mengikuti.

Tabel 3. Perbandingan hasil belajar siswa pada siklus 1 dan 2

\begin{tabular}{ccc}
\hline \multirow{2}{*}{ Hasil Belajar Siswa } & \multicolumn{2}{c}{ Kategori } \\
\cline { 2 - 3 } & Belum Memenuhi KKM & Sudah Memenuhi KKM \\
\hline Siklus 1 & 18 siswa (86\%) & 3 siswa (14\%) \\
Siklus 2 & 8 siswa (38\%) & 13 siswa (62\%) \\
\hline
\end{tabular}

Persentase peningkatan hasil belajar siswa secara klasikal ditunjukkan pada tabel 3, dimana perbandingan hasil belajar siswa baru mencapai 47,6\%. Meskipun peningkatan dari hasil belajar siswa belum memenuhi standar klasikal, namun 95\% siswa mengalami peningkatan hasil belajar. Hal ini ditunjukkan pada perbandingan grafik hasil belajar siswa pada siklus 1 dan siklus 2. Dari total 21 siswa, hanya satu siswa yang mengalami penurunan.

Terjadinya peningkatan persentase hasil belajar siswa tersebut merupakan salah satu indikator bahwa ada peningkatan pemahaman siswa terhadap materi yang dipelajari. Peningkatan materi yang dipelajari ditunjukkan oleh ketuntasan siswa dalam pemenuhan Kriteria Ketuntasan Minimal (KKM) dari setiap Kompetensi Dasar (KD). Bagi siswa yang masih belum mencapai KKM, maka diharuskan untuk melakukan remidi dengan beban tugas tidak terstruktur. 
Persentase peningkatan hasil belajar siswa kelas VIIA MTs Darul Ulum Muhammadiyah Galur masih belum mencapai standar ketuntasan individual maupun klasikal. Namun, berdasarkan evaluasi dari keseluruhan proses, maka ketrampilan dan pemahaman siswa dalam mempelajari materi Klasifikasi Makhuk Hidup meningkat. Hal ini didukung dengan penilaian sikap dan keterlibatan siswa dalam mengikuti penelitian. Rata-rata ketrampilan siswa naik lebih dari $86 \%$. Sehingga, dalam hal ini penelitian tindakan kelas dianggap cukup dan berhasil meningkatkan hasil belajar siswa.

\section{SIMPULAN}

Simpulan dari penelitian ini adalah strategi Quantum Learning sangat membantu siswa menjadi lebih aktif dalam melakukan pembelajaran. Materi Klasifikasi Makhluk Hidup merupakan materi yang memiliki kesulitan dalam penghafalan istilah penulisan dan pelafadzan ilmiah, sehingga dengan memberi nama atau label pada jenis tumbuhan di lingkungan madrasah dapat membantu siswa menghafal dan mempelajari dengan mudah. Oleh karena itu, hasil belajar siswa menjadi meningkat. Hal ini ditunjukkan dengan kenaikan persentase capaiaan KKM dari siklus 1 yang hanya $14 \%$ menjadi $62 \%$ pada siklus 2 . Meskipun belum mencapai standar ketuntasan individual dan klasikal, namun hasil belajar siswa rata-rata meningkat sebesar $95 \%$.

\section{REFERENSI}

Abdurrahman, M. (2003). Pendidikan bagi anak berkesulitan belajar. Jakarta: Rineka Cipta.

MacIsaac, D. (1995). An introduction to action research. http://physicsed.buffalostate.edu/danowner/actionrsch.html

O'Brien, R. (1998). An overview of the methodological approach of action research. http://web.net/ robrien/papers/xx ar final.htm

Purba, G. O. M. S. (2009). Gambaran penerapan quantum learning pada Mahasiswa Psikologi Universitas Sumatera Utara. Universitas Sumatra Utara.

Purwanto, M. N., Rifa'i, A., \& Anni, C. T. (2009). Psikologi pendidikan. In Remaja Rosdakarya. PT Remaja Rosdakarya.

Syah, M. (2013). Psikologi pendidikan dengan pendekatan baru. PT Remaja Rosdakarya.

Widayati, S. (2016). Upaya meningkatkan hasil belajar ilmu pengetahuan alam materi klasifikasi makhluk hidup melalui metode problem based learning (PBL) pada siswa kelas VII-F UPTD SMP Negeri 1 Rejotangan Tulungagung. 